\title{
NUTRITIONAL AND SENSORY PROFILING OF THE AFRICAN GIANT LAND SNAIL FED COMMERCIAL-TYPE AND LEAF-BASED DIETS IN A RAIN-FOREST ECOLOGY
}

\author{
Kalio GA ${ }^{1}$ and I Etela ${ }^{2 *}$
}
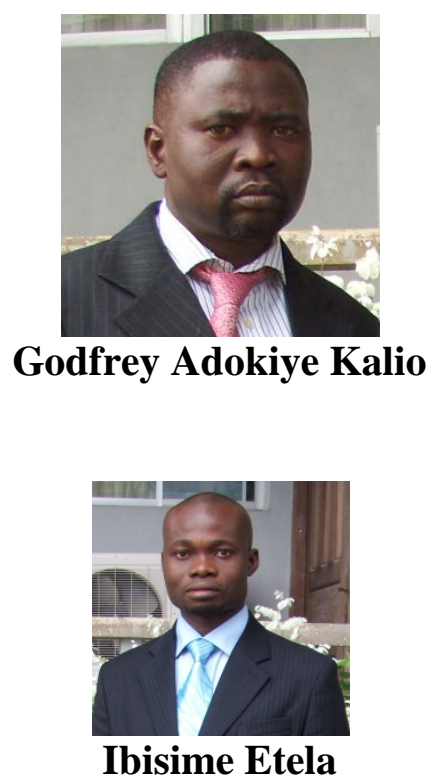

*Corresponding author email: ibisime.etela@uniport.edu.ng

${ }^{1}$ Department of Agriculture, Rivers State University of Education, PMB 5047, Ndele, Nigeria.

${ }^{2}$ Department of Animal Science and Fisheries, University of Port Harcourt, PMB 5323, Port Harcourt, Rivers State, Nigeria. 
ABSTRACT

Nutritional and organoleptic properties of the African giant land snails (Archachatina marginata) were investigated using 96 healthy-looking growing snails maintained on broiler starter mash (BSM) as control, Talinium triangulare or waterleaf, Centrosema molle or centro leaves, and Carica papaya or pawpaw leaves for 16 weeks. This study was set up as a completely randomized design (CRD) with the snails allocated to 4 treatment groups (broiler starter mash (BSM) as control; Talinium triangulare leaves or waterleaf; Centrosema molle or centro leaves; Carica papaya or pawpaw leaves) and 3 replications each of 8 snails (giving a total of 24 snails per treatment group). At the end of the 16-week period, 4 snails were each harvested at random from the 3 replicates of each of the 4 treatments, sacrificed, processed and analyzed. Dry matter (DM), ash, fat or ether extract (EE) and nitrogen-free extract (NFE) were higher $(P<$ $0.05)$ in the BSM group, while crude fibre (CF) was higher $(P<0.05)$ in centro leaves (34.2 g/100 g) and crude protein (CP) was higher in pawpaw leaves. Meancholesterol level was very low $(0.003 \pm 0.0006 \mathrm{mg} / 100 \mathrm{~g})$ in the snail. Negative correlation $(\mathrm{r}=\mathrm{-}$ 0.99; $P<0.05$ ) was recorded between diet CF and moisture content of the snail meat, while feed EE had a positive correlation $(r=0.98 ; P<0.05)$ with snail cholesterol level. Based on tastiness, toughness and tenderness of the snails fried and stewed with spices or only steamed without spices, preference ranking in descending order gave pawpaw leaves $>$ BSM $=$ centro leaves $>$ waterleaf. Thus, snails fed pawpaw leaves performed better than the control diet and could be exploited as a cheap feed resource for smallholder snail production in the humid tropics. Low fat and cholesterol levels in the African giant land snail make it very suitable for ameliorating human cardiovascular-related diseases.

Key words: Composition, nutrient, palatability, sensory, snail 


\section{INTRODUCTION}

In Nigeria, meat proteins come largely from conventional sources such as chicken, cattle, sheep, goats and swine or pigs. However, these major animal protein sources have continued to diminish in their capacity to meet demands due to persistent drought, diseases, high cost of feed, primitive animal husbandry techniques and low productivity by local animal breeds. Increasing human population coupled with rising standards of living has placed great pressure on existing conventional sources of animal protein [1]. There is, therefore, need to source for other non-conventional meat protein sources that are equally nutritious yet relatively capable to bridge the gap. Micro-livestock such as the giant snail has been domesticated to solve the problem of protein insufficiency [2,3]. Snails are the largest group of molluscs constituting the largest animal group next to arthropods. The giant land snails are non-conventional protein sources whose meat is a highly relished delicacy (also known as 'Congo meat') and constitutes an important source of animal protein in many coastal communities of Nigeria and other parts of Africa [4].

Meat of snail is palatable, nutritious and rich in essential amino acids such as lysine, leucine, isoleucine and phenylalanine as well as high iron contents $[5,6,7]$. Snails have also been recommended for the treatment of anaemia, asthma, high blood pressure and other related ailments due to their relatively low cholesterol levels [8, 10]. It is believed that the nutritional quality of snail meat depends on the nutritional quality of feed they consume in the wild or in captivity, which in turn determines their preference and palatability by man. But there is paucity of information on the relationship between the nutritional composition of feed consumed by snails and the nutritional value/ palatability of their edible flesh. Hence, this study investigated the flesh quality and palatability of the African giant land snail (Archachatina marginata) fed commercial broiler starter and green leafy materials from three common humid tropical plants (Carica papaya, Centrosema molle and Talinium triangulare).

\section{MATERIALS AND METHOD}

\section{Experimental site and design}

A 16-week completely randomized design (CRD) feeding trial was conducted at the Teaching and Research Farm of the Rivers State University of Education, Ndele Campus, Nigeria. The work used 96 healthy-looking growing Archachatina marginata snails allocated to 4 treatment groups: broiler starter mash (BSM); Talinium triangulare leaves of waterleaf; Centrosema molle or centro leaves; and Carica papaya or pawpaw leaves. At termination after the 16 weeks feeding trial, 4 snails from each of the 3 replicates per treatment were harvested, sacrificed, eviscerated and properly cleaned in the Animal Science Laboratory prior to their preparation for proximate analysis and commencement of the preference and palatability experiment.

\section{Proximate analysis of edible flesh of snail}

The sacrificed snails were carefully de-shelled to expose the fresh and intact edible flesh, which was then dried and prepared into powder before they were sent to the 
Food Science and Technology Laboratory of the Rivers State University of Science and Technology in Port Harcourt for proximate analysis. The powder for each replicate per treatment was subjected to different processing methods of consumption. Moisture, ash and crude fibre (CF) contents of the flesh were determined using standard methods [11]. Nitrogen was determined using the micro-Kjeldahl method as described by Pearson [12] and the percentage nitrogen multiplied by 6.25 to derive the crude protein (CP) content. Lipid (fat) content was determined by the Bligh-Dyer method [13]. Carbohydrate was computed by difference as $100 \%$ minus the sum for the values for protein, moisture, fibre, fat and ash contents.

The mineral contents were analyzed from solutions obtained by first ashing the powdery samples at $550^{\circ} \mathrm{C}$ and dissolving the ash with distilled and deionized water containing a few drops of concentrated hydrochloric acid in $500 \mathrm{ml}$ conical flasks. Phosphorus (P) was determined colorimetrically using Spectronic-20 (Gallenkamp, $\mathrm{UK})$ as described by Pearson [12] with potassium tetraoxo (V) phosphate $\left(\mathrm{KH}_{2} \mathrm{PO}_{4}\right)$ as a standard. Sodium $(\mathrm{Na})$ and potassium $(\mathrm{K})$ were determined using a flame photometer (Model 405, Corning, UK) using sodium chloride $(\mathrm{NaCl})$ and potassium chloride $(\mathrm{KCl})$ to prepare the standards. All other metals were determined by means of an atomic absorption spectrophotometer (Model SP9, PyeUnican, UK).

\section{Sensory evaluation (preference and palatability trial) of edible snail}

Two sets of the same snail meat were prepared in 10 minutes each with one set fried and stewed with spices, and the other set was steamed without spices. After preparation, one set was presented to each of the 12 "taste panelists" in a saucer at a time using the "cafeteria method". Twelve taste points (replications) having the four pieces of snail meat representing the four treatment groups were presented to the panelists. A preliminary instruction session was conducted between the researcher and the "taste panelists" prior to the commencement of the preference and palatability trial. Specifically, panelists were advised to avoid eating, drinking or smoking, at least, 30 minutes before each sensory profiling test. They were also instructed to avoid conversations and discussions during sensory evaluation sessions and to test one parameter at a time. At the end of the testing of a particular sample, panelists were made to rinse their mouths with water. Sensory evaluation score sheets (questionnaires) were also given to the taste panelists for assessment. The parameters tested were tastiness, toughness, and tenderness with scores assigned to each treatment group based on the parameters tested. A maximum score of 4 points was awarded for the best parameter and a least score of 1 point awarded to the worst parameter, respectively, for a particular treatment.

\section{Statistical analyses}

Data obtained for the feed proximate composition were analyzed as completely randomized design (CRD) with 4 treatments (dietary sources) and 2 replications, while data from the 16 weeks snail feeding trial were analyzed as CRD with 4 treatments and 3 replicates using analysis of variance (ANOVA) procedures as described by Gomez and Gomez [14]. Least significant difference (LSD) at the 5\% probability option was used for mean separation wherever the $F$-test recorded significant differences among treatment means [15]. At the end of the sensory 
evaluation exercise, the score sheets were collected from the panelists and the scores collated for computing preference ranking.

\section{RESULTS}

Table 1 shows the chemical composition of the four dietary sources used for the study. The results indicated that the control diet recorded higher values for dry matter $(\mathrm{DM})$, ash, fat or ether extract (EE) and nitrogen-free extract (NFE), except for crude fibre (CF) which was higher $(P<0.05)$ in centro leaves $(34.2 \mathrm{~g} / 100 \mathrm{~g})$ and crude protein (CP) which was higher in pawpaw leaves $(22.7 \mathrm{~g} / 100 \mathrm{~g})$. The recorded differences in chemical composition are indications to likely differences in their utilization by the snails.

The proximate composition of the edible flesh (meat) of Archachatina marginata (the African giant land snail) fed four dietary sources is presented in Table 2. The moisture content was significantly different $(P<0.05)$ ranging between $14.5 \mathrm{~g} / 100 \mathrm{~g}$ and16.0 $\mathrm{g} / 100 \mathrm{~g}$ for the snails fed centro leaves and waterleaf, respectively. The ash content in the snails also varied significantly $(P<0.05)$, from $7.6 \mathrm{~g} / 100 \mathrm{~g}$ for snails fed waterleaf to $8.5 \mathrm{~g} / 100 \mathrm{~g}$ for the control diet. The percentage of fat contained in the snail meat exposed to the four dietary sources were also significantly different $(P<0.05)$ with those fed centro leaves recording the highest compared to the rest of the treatment groups. The carbohydrate content were also significantly different $(P<0.05)$ ranging from $10.6 \mathrm{~g} / 100 \mathrm{~g}$ for the pawpaw leaves fed snails to $28.6 \mathrm{~g} / 100 \mathrm{~g}$ for the centro leaves fed snails. The variations in crude protein contents differed significantly $(P<$ 0.05 ) between $37.8 \mathrm{~g} / 100 \mathrm{~g}$ for the centro leaves fed snails and $39.3 \mathrm{~g} / 100 \mathrm{~g}$ for the pawpaw leaves fed snails. Correlation analysis showed that the snail moisture content had a negative relationship $(r=-0.99 ; P<0.05)$ with the feed CF content.

The mineral and cholesterol concentrations in the edible flesh of the African giant land snail fed four dietary sources are presented in Table 3. Results indicated that the mineral contents were lower $(P<0.05)$ for the centro leaves fed snail group and higher for the control diet (BSM) fed snail group, except copper $(\mathrm{Cu})$ content which was higher in the waterleaf fed snail group. Similarly, the cholesterol levels in the flesh of the snails were significantly different $(P<0.05)$ with the pawpaw leaves fed snail group recording the lowest $(0.002 \mathrm{mg} / 100 \mathrm{~g})$ and the control diet fed snail group recording the highest $(0.005 \mathrm{mg} / 100 \mathrm{~g})$. The results on cholesterol content in the flesh of the snail showed a positive correlation $(r=0.98 ; P<0.05)$ with the feed EE content.

Table 4 presents the results from sensory evaluation of the meat from snails based on two processing methods using tastiness, toughness and tenderness as criteria for determining consumption preference. The overall response of the taste panelists as presented in Table 4 showed that the meat of snails fed pawpaw leaves were most preferred, while the meat from the snails fed waterleaf was least preferred. Based on the preference ranking for both processing methods, the trend in decreasing order of preference was pawpaw leaves $>$ BSM $($ as control) $=$ centro leaves $>$ waterleaf. 


\section{DISCUSSION}

Chemical composition of the four dietary sources as indicated in Table 1 suggests that pawpaw leaves would be more nutritious based on the very low crude fibre (CF) and relatively higher crude protein (CP) contents. The recorded differences in chemical composition are indications of likely differences in their utilization by the snails. The results further suggest that pawpaw leaves would be more nutritious based on the relatively higher $\mathrm{CP}$ and lower EE contents. Also, the extremely high moisture content of waterleaf means the snails are more likely to perform worse than those on other dietary treatments since the snails will be receiving the least nutrients per unit weight of waterleaf consumed.

Recorded moisture content of the snails were different from the 76.56-78.65\% reported by other workers who investigated the nutritional status of four species of giant snails from the wild in Ekiti State, South Western Nigeria [16]. These variations may be attributed to the natural conditions to which the snails were exposed such as gaining regular access to natural succulent plants and rainfall, as well as freely available pools of water in the wild. The higher moisture content $(16.0 \mathrm{~g} / 100 \mathrm{~g})$ observed in the meat of snails fed waterleaf may be due to the very succulent nature of the plant. Hence, the high moisture waterleaf consumed by the snails is most likely to have increased their body fluid contents [17]. The values recorded for ash content were also higher than the 1.35 to $1.44 \%$ reported by others [16]. The higher ash content in snail meat fed BSM may be attributed to the high amount of mineral availability in the feed through the natural feed ingredients. Similarly, the carbohydrate, fat and CP contents in the meat of the snails were also higher than the values reported for four species of snails earlier studied [16]. Also, the range 10.3$11.2 \mathrm{~g} / 100 \mathrm{~g}$ recorded as fat content for the edible portion of the snail is higher than the range $0.9-1.5 \%$ reported for snails by other workers in Nigeria [4]. Differences in diet type and weather conditions (humid vs sub-humid zones) could be the major reason for these marked discrepancies.

Table 3 shows the mineral and cholesterol compositions of snail meat from the four dietary sources investigated. The snails fed BSM were superior in sodium (Na), magnesium (Mg), potassium $(\mathrm{K})$, calcium $(\mathrm{Ca})$, manganese $(\mathrm{Mn})$, iron $(\mathrm{Fe})$, phosphorus (P) and zinc (Zn) concentrations, while the snails fed waterleaf were only superior to other treatments in Fe and copper $(\mathrm{Cu})$ concentrations. The average $\mathrm{Ca}$ content $(165 \pm 7.2 \mathrm{mg} / 100 \mathrm{~g})$ was lower than the $185.7 \mathrm{mg} / 100 \mathrm{~g}$ reported, while the mean values reported for $\mathrm{P}(238 \pm 31.5 \mathrm{mg} / 100 \mathrm{~g}$ vs $61.2 \mathrm{mg} / 100 \mathrm{~g}), \mathrm{K}$ (373 \pm 30.7 $\mathrm{mg} / 100 \mathrm{~g}$ vs $63.3 \mathrm{mg} / 100 \mathrm{~g})$, and Fe (16.1 mg/100 g vs $1.4 \mathrm{mg} / 100 \mathrm{~g})$ were higher than those reported by Imevbore and Ademosun [18]. The observed $\mathrm{Ca}, \mathrm{P}, \mathrm{K}$ and Fe concentrations in the snail meat were also higher than those reported for beef, broiler meat, goat meat (chevon), meat from sheep (mutton) and pork from swine or pigs [18].

Hence, snails appear to be better sources for supplying nutrient elements via their meat. The availability of $\mathrm{Fe}$ in substantial quantity in snail meat will also aid 
metabolism in the body by facilitating the oxidation of carbohydrates, proteins and fats [19]. Furthermore, the high concentrations of Ca found in the snail meat show that the consumption of snail could increase Ca levels in the body and contribute to normal blood clotting [16]. The mean cholesterol level of $0.003 \pm 0.0006 \mathrm{mg} / 100 \mathrm{~g}$ ) for the snail meat was lower than the $0.42 \mathrm{mg} / 100 \mathrm{~g}$ reported by others for snail and those reported in other conventional animal protein sources such as beef $(1.06 \mathrm{mg} / 100$ g), broiler meat $(0.84 \mathrm{mg} / 100 \mathrm{~g})$, goat meat $(0.76 \mathrm{mg} / 100 \mathrm{~g})$, mutton $(0.62 \mathrm{mg} / 100 \mathrm{~g})$ and pork (1.02 mg/100 g) in comparison [18]. The recorded composition of the meat from snail accounts for the reason why it is recommended for persons suffering from high blood pressure and arteriosclerosis [10; 20; 21].

Studies on sensory profiling of snail meat was done to ascertain the impact of the diets utilized by snails in their natural habitats (wild forest) or in captivity may have on their sensory or organoleptic qualities (taste; toughness; tenderness) and how these parameters may influence the palatability and preference for snail meat by consumers. The snail meat was presented as 'Congo meat' being one of the most acceptable delicacies (fried and stewed with spices) in most restaurants in Nigeria. The investigation revealed that the treatment groups consisting of the leaf-based diets had the first two higher rankings with meat from snails fed with pawpaw leaves emerging as the most preferred combining all the sensory profiling parameters investigated (Table 4). Tastiness, toughness and tenderness are important organoleptic qualities that will be very beneficial to proprietors of restaurants to guarantee preference by consumers (customers) and the keeping quality of snail meat.

\section{CONCLUSION}

The African giant land snail (Archachatina marginata) is a non-conventional wildlife animal protein source although, it is now being farmed to reduce stress on the wild stocks and because it is a highly relished delicacy (also referred to as 'Congo meat') in Nigeria and some parts of Africa. This study revealed that the meat from snail is rich in nutrients compared to the more conventional animal protein sources such as cattle, chicken, goat, sheep and swine or pig. The study also suggests that the nutritious quality of snail meat is greatly influenced by the type and quality of diet supplied to the snail. The edible flesh (meat) of snails fed waterleaf, centro and pawpaw leaves were observed to be of comparable quality and preferred by consumers to those fed with a commercial broiler starter mash (BSM). This result will be very beneficial to snail farmers by reducing their cost of production that would have accrued from high feed prices. In addition, it would help to meet consumers' demands in terms of providing the right nutrition, meeting daily intake of animal protein as well as providing necessary remediation to challenges of ill-health in man. The use of green leafy feeds as used in this study is recommended as a means for reducing production cost in snail farming. 


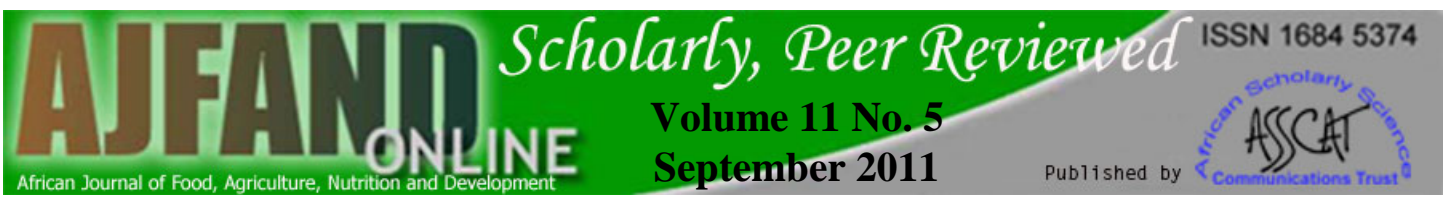

Table 1: Chemical composition of the four dietary sources used for the study

\begin{tabular}{|c|c|c|c|c|c|c|}
\hline \multirow[b]{2}{*}{ Nutrient composition } & \multicolumn{4}{|c|}{ Dietary source (g/100 g) } & \multirow[b]{2}{*}{ Mean } & \multirow{2}{*}{$\begin{array}{c}\mathrm{SE} \\
(\mathrm{df}=4)\end{array}$} \\
\hline & $\begin{array}{c}\text { Broiler starter } \\
\text { mash (control) }\end{array}$ & $\begin{array}{l}\text { Talinium } \\
\text { triangulare }\end{array}$ & $\begin{array}{c}\text { Centrosema } \\
\text { molle }\end{array}$ & $\begin{array}{l}\text { Carica } \\
\text { papaya }\end{array}$ & & \\
\hline Dry matter (DM) & $88.8^{\mathrm{a}}$ & $9.8^{\mathrm{b}}$ & $21.5^{\mathrm{b}}$ & $22.1^{\mathrm{b}}$ & 35.6 & 17.97 \\
\hline Ash & $53.8^{\mathrm{a}}$ & $35.2^{\mathrm{a}}$ & $8.1^{\mathrm{b}}$ & $7.6^{\mathrm{b}}$ & 26.2 & 11.24 \\
\hline Crude fibre (CF) & $16.4^{\mathrm{b}}$ & $11.1^{\mathrm{b}}$ & $34.2^{\mathrm{a}}$ & $10.5^{b}$ & 18.1 & 5.54 \\
\hline Crude protein (CP) & $15.3^{\mathrm{b}}$ & $20.5^{\mathrm{a}}$ & $18.2^{\mathrm{b}}$ & $22.7^{\mathrm{a}}$ & 19.2 & 1.59 \\
\hline Fat or ether extract (EE) & $4.0^{\mathrm{a}}$ & $1.5^{\mathrm{bc}}$ & $2.1^{\mathrm{b}}$ & $0.4^{\mathrm{c}}$ & 2.0 & 0.76 \\
\hline Nitrogen-free extract (NFE) & $47.8^{\mathrm{a}}$ & $31.7^{\mathrm{b}}$ & $37.4^{\mathrm{b}}$ & $36.7^{\mathrm{b}}$ & 38.4 & 3.38 \\
\hline
\end{tabular}

Table 2:Proximate composition of edible flesh of the African giant land snail (Archachatina marginata) fed four dietary sources

\begin{tabular}{lcccccc}
\hline \multirow{2}{*}{ Nutrient content } & \multicolumn{3}{c}{ Dietary source (g/100 g) } & & \multirow{2}{*}{ SE } \\
\cline { 2 - 5 } & $\begin{array}{c}\text { Broiler starter } \\
\text { mash (control) }\end{array}$ & $\begin{array}{c}\text { Talinium } \\
\text { triangulare }\end{array}$ & $\begin{array}{c}\text { Centrosema } \\
\text { molle }\end{array}$ & $\begin{array}{c}\text { Carica } \\
\text { papaya }\end{array}$ & Mean & $\begin{array}{c}\text { (df = 8) } \\
\text { Moisture }\end{array} 1^{\mathrm{a}}$ \\
Ash & $8.5^{\mathrm{a}}$ & $16.0^{\mathrm{a}}$ & $14.5^{\mathrm{b}}$ & $15.8^{\mathrm{a}}$ & 15.5 & 0.33 \\
Fat or ether extract (EE) & $10.3^{\mathrm{b}}$ & $7.6^{\mathrm{c}}$ & $7.8^{\mathrm{bc}}$ & $8.1^{\mathrm{ab}}$ & 8.0 & 0.20 \\
Carbohydrate & $27.6^{\mathrm{a}}$ & $26.1^{\mathrm{a}}$ & $28.6^{\mathrm{a}}$ & $10.6^{\mathrm{b}}$ & 23.2 & 4.24 \\
Crude protein (CP) & $38.2^{\mathrm{b}}$ & $39.3^{\mathrm{a}}$ & $37.8^{\mathrm{b}}$ & $38.0^{\mathrm{b}}$ & 38.3 & 0.34 \\
\hline
\end{tabular}

${ }^{\mathrm{a}, \mathrm{b}, \mathrm{c}}$ Means bearing different superscripts on the same row are significantly different $(P<0.05)$. 


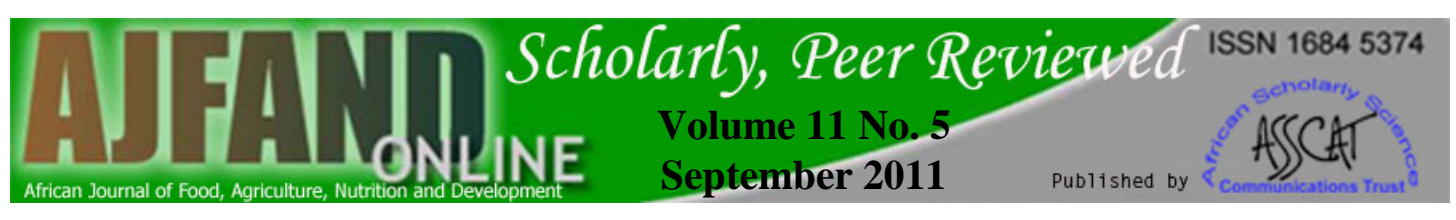

Table 3: Mineral and cholesterol concentrations in the edible flesh of the African giant land snail (Archachatina marginata) fed four dietary sources

\begin{tabular}{|c|c|c|c|c|c|c|}
\hline \multirow[b]{2}{*}{ Nutrient content } & \multicolumn{4}{|c|}{ Dietary source (mg/100 g) } & \multirow[b]{2}{*}{ Mean } & \multirow[b]{2}{*}{$\begin{array}{c}\mathrm{SE} \\
(\mathrm{df}=8)\end{array}$} \\
\hline & $\begin{array}{l}\text { Broiler starter } \\
\text { mash (control) }\end{array}$ & $\begin{array}{l}\text { Talinium } \\
\text { triangulare }\end{array}$ & $\begin{array}{c}\text { Centrosema } \\
\text { molle }\end{array}$ & $\begin{array}{l}\text { Carica } \\
\text { papaya }\end{array}$ & & \\
\hline Sodium (Na) & $37.1^{\mathrm{a}}$ & $36.5^{\mathrm{ab}}$ & $35.2^{\mathrm{bc}}$ & $36.2^{b}$ & 36.3 & 0.40 \\
\hline Magnesium (Mg) & $260^{\mathrm{a}}$ & $259^{\mathrm{a}}$ & $180^{\mathrm{b}}$ & $200^{\mathrm{b}}$ & 225 & 20.5 \\
\hline Potassium (K) & $450^{\mathrm{a}}$ & $340^{\mathrm{bc}}$ & $310^{\mathrm{c}}$ & $390^{\mathrm{ab}}$ & 373 & 30.7 \\
\hline Calcium (Ca) & $175^{\mathrm{a}}$ & $170^{\mathrm{a}}$ & $144^{\mathrm{b}}$ & $172^{\mathrm{a}}$ & 165 & 7.2 \\
\hline Manganese (Mn) & $0.25^{\mathrm{a}}$ & $0.21^{\mathrm{a}}$ & $0.15^{\mathrm{b}}$ & $0.22^{\mathrm{a}}$ & 0.21 & 0.021 \\
\hline Iron (Fe) & $16.8^{\mathrm{a}}$ & $16.8^{\mathrm{a}}$ & $14.5^{\mathrm{b}}$ & $16.1^{\mathrm{a}}$ & 16.1 & 0.54 \\
\hline Copper (Cu) & $0.75^{\mathrm{a}}$ & $0.76^{\mathrm{a}}$ & $0.56^{\mathrm{b}}$ & $0.65^{\mathrm{b}}$ & 0.68 & 0.047 \\
\hline Phosphorus (P) & $277^{\mathrm{a}}$ & $276^{\mathrm{a}}$ & $145^{\mathrm{b}}$ & $255^{\mathrm{a}}$ & 238 & 31.5 \\
\hline Zinc (Zn) & $9.6^{\mathrm{a}}$ & $9.4^{\mathrm{a}}$ & $7.5^{\mathrm{b}}$ & $8.7^{\mathrm{a}}$ & 8.8 & 0.47 \\
\hline Cholesterol & $0.005^{\mathrm{a}}$ & $0.003^{\mathrm{b}}$ & $0.003^{\mathrm{b}}$ & $0.002^{\mathrm{b}}$ & 0.003 & 0.0006 \\
\hline
\end{tabular}

${ }^{\mathrm{a}, \mathrm{b}, \mathrm{c}}$ Means bearing different superscripts on the same row are significantly different $(P<0.05)$. 
Table 4: Sensory profiling of snail meat based on tastiness, toughness and tenderness from four dietary sources and processed using two methods

\begin{tabular}{lcccc}
\hline \multirow{2}{*}{ Processing method } & \multicolumn{3}{c}{ Palatability score* } \\
\cline { 2 - 5 } & $\begin{array}{c}\text { Broiler starter } \\
\text { mash (control) }\end{array}$ & $\begin{array}{c}\text { Talinium } \\
\text { triangulare }\end{array}$ & $\begin{array}{c}\text { Centrosema } \\
\text { molle }\end{array}$ & $\begin{array}{c}\text { Carica } \\
\text { papaya }\end{array}$ \\
\hline Fried and stewed with spices: & 2.8 & 2.3 & 1.3 & 2.8 \\
Tastiness & 2.8 & 2.8 & 2.6 & 1.8 \\
Toughness & 1.5 & 1.6 & 3.4 & 3.5 \\
Tenderness & 2.4 & 2.2 & 2.4 & 2.7 \\
Mean & & & & \\
Steamed without spices: & 2.5 & 2.3 & 2.6 & 2.6 \\
Tastiness & 2.3 & 2.5 & 2.4 & 2.8 \\
Toughness & 2.7 & 2.5 & 2.5 & 2.4 \\
Tenderness & 2.5 & 2.4 & 2.5 & 2.6 \\
Mean & $2^{\text {nd }}$ & $3^{\text {rd }}$ & $2^{\text {nd }}$ & $1^{\text {st }}$ \\
\hline
\end{tabular}

*Palatability score: 1 was awarded for worst, while 4 was awarded for best parameter 


\section{REFERENCES}

1. OyenugaVA Agriculture in Nigeria. Rome, Italy: FAO (Food and Agricultural Organisation), 1968.

2. NRC (National Research Council) Microlivestock: Little-Known Small Animals with a Promising Economic Future, National Academy Press, Washington, D.C., 1991.

3. Akinnusi $\mathbf{O}$ Introduction to Snails and Snail Farming. Real Solutions Computers, 23 Quarry Road, Abeokuta, Nigeria, 1998: 85 pp.

4. Omole AJ, Taiwo AA and JA Amusan Practical Snail Farming - Technical Guide / Bulletin, Institute of Agricultural Research and Training, Moor Plantation, Ibadan, Nigeria, 2007: 26 pp.

5. Imevbore EA Management Techniques in Rearing African Giant Land Snail (Archachatina marginata). Ph.D Thesis, University of Ibadan, Nigeria, 1990.

6. Stievenart C Shell morphology, growth, reproduction and aestivation by African snails. Laboratory observations on Archachatina marginata Saturalis, Achatina achatina and Achatina fulica. PhD Thesis, no.5, 1996: 206 pp.

7. Ebenebe CI Mini-livestock production in Nigeria. The present and the future. Proc., $5^{\text {th }}$ Ann., Conf., ASAN, Port Harcourt, Nigeria, Sept. 19-22, 2000.

8. AwesuMO The biology and management of the African giant land snail (Archachatina marginata). Unpublished M.Phil Dissertation, University of Ibadan, 1980: 198.

9. Adu OA, Ojuroougbe AO and AJ Omole Performance and carcass analysis of Giant Land Snails (Archachatina marginata) fed different concentrates. Proceedings of the $27^{\text {th }}$ Annual Conference of the Nigerian Society for Animal Production (NSAP), Federal University of Technology, Akure (FUTA), March 17-21: 2002: 325-327.

10. Akinnusi FAO Comparative Evaluation of fresh fruits leaves and concentrate feed on the growth and reproductive performance of the African land snail (Archachatina marginata). Proceedings of the $27^{\text {th }}$ Annual Conference of the Nigerian Society for Animal Production (NSAP), Federal University of Technology, Akure (FUTA), March 17-21, 2002: 328-320.

11. AOAC. Association of Official Analytical Chemists, Official Methods of Analysis, 15th edition, Washington, DC, USA, 1990: 1298 pp.

12. Pearson DChemical Analysis of Foods. 7th Ed. London: J \& A Churchill, 1976. 
13. Bligh EG and WJ Dyer 1959. A rapid method of total lipid extraction and purification. Can. J. Biochem. and Physiol., 1959; 37: 911-917.

14. Gomez KA and AA Gomez Statistical Procedures for Agricultural Research, $2^{\text {nd }}$ edition, John Wiley and Sons, New York, 1984.

15. Steel RGD and JH Torrie Principles and procedures of statistics: A Biometrical Approach, $2^{\text {nd }}$ edition, McGraw-Hill Book Co. Inc., New York, 1980: 631 pp.

16. Fagbuaro O, Oso JA, Edward JB and RF Ogunleye 2006. Nutritional status of four species of giant land snail in Nigeria. J. Zhejiang Univ. Sci. B., 2006; 7: 686-689. doi: 10.1631/jzus.2009.B0686.

17. Olusanya $\mathbf{S}$ and $\mathbf{M J}$ Isoun The body fluids and urinary system. In:Heath $\mathbf{E}$ and S Olusanya (eds), Anatomy and Physiology of Tropical Livestock. ELBS/Longman Publishers, U.K., 1988: 68.

18. Imevbore EA and AA Ademosun The nutritive value of the African giant land snail Archachatina marginata. J. Anim. Prod. Res., 1988; 8: 76-87.

19. Bender A Meat and Meat Products in Human Nutrition in Developing Countries FAO Food and Nutrition. Rome, Italy: FAO (Food and Agricultural Organisation), 1992.

20. Akinnusi O Introduction to Snails and Snail Farming. Abeokuta-Ibadan. Trilas Excuisite Ventures, 2004: 90.

21. Tell Communication and Songhai Centre Course manual on Entrepreneurship Opportunities in Agribusiness. A Shell Sustainable Community Development Programme, 2006. 